f. med. Genet. (1967). 4, 280.

\title{
Vascular Disease of the Central Nervous System in Wales
}

\author{
DAVID J. B. ASHLEY
}

From Morriston Hospital, Swansea

Death as a consequence of a vascular accident involving the central nervous system is a common end to life in Britain. In 1963, $11 \%$ of deaths among men and $17 \%$ of deaths among women were attributed to this cause. Most commonly the cerebrovascular accident is, in turn, attributable to degenerative arteriosclerotic disease of the vessels of the brain. I have previously shown (Ashley, 1967) that there is an excess of cases of arteriosclerotic disease involving the heart in Wales and that this excess can be correlated with the distribution of 'Welshness' reflected in the proportion of the population who speak the Welsh language and in the proportion who have surnames that are typically Welsh (Ashley and Davies, 1966a). This paper comprises a study of the distribution of vascular disease of the central nervous system in Wales and its relation to Welshness, as reflected in the two parameters, Welsh speaking and Welsh names.

The Registrar General $(1965,1966)$ gave values of the Standardized Mortality Ratio (S.M.R.) for vascular disease of the central nervous system for the Welsh Hospital Board area, which is coterminous with the Principality of Wales. In 1963 the S.M.R. for men for deaths from this cause was 110 and for women 116. In 1964 the S.M.R. for men was 114 and for women 111. All four of these values are significantly greater than 100 .

\section{Data for Wales}

Distribution of Deaths within Wales. The ability to speak the Welsh language is the great cultural difference between the Welsh and the nonWelsh within Wales. The census of 1961 (Registrar General, 1962b) included questions on the ability to speak this language and on the basis of this report the Principality may conveniently be divided into three zones. In the 'high Welsh' zone, the counties of Anglesey, Caernarvon, Cardigan, Carmar-

\footnotetext{
Received May 5, 1967.
}

then, and Merioneth, more than $70 \%$ of the population over the age of 3 claimed to be Welsh speaking. In the intermediate Welsh zone, the counties of Brecknock, Denbigh, Flint, Glamorgan, Montgomery, and Pembroke and the county boroughs of Merthyr Tydfil and Swansea, between 15 and 45\% of the population claimed to be Welsh speaking, while in the low Welsh zone, the counties of Monmouth and Radnor and the county boroughs of Cardiff and Newport less than $10 \%$ of the population claimed to be Welsh speaking.

The deaths for 1958-1962, classified by the Registrar General $(1960,1961,1962 a, 1963,1964)$ under cause B 22, vascular disease of the central nervous system, were analysed for these three areas. As the death rate for the whole of England and Wales varies in town and country areas, a corrected Standardized Mortality Ratio was calculated in which the numbers of deaths expected in rural areas, and in towns of less than $50,000,50,000$ to 100,000 , and more than 100,000 population, were determined separately. This course was undertaken because $93 \%$ of the population of the high Welsh zone live in the country while $47 \%$ of the population of the intermediate Welsh zone do so, and only $29 \%$ of the people of the low Welsh zone are countrymen. On the other hand $49 \%$ of the people of the low Welsh zone live in towns of more than 100,000 people, $18 \%$ of those in the intermediate Welsh zone do so, and there are no towns of this size in the high Welsh zone.

The data from this analysis (Table I) show that there is a higher mortality from vascular disease of the central nervous system both in men and in women in the high Welsh zone than in the intermediate Welsh zone and that the rate is again lower in the low Welsh zone for both sexes.

Analysis by Surnames. The surnames regarded as Welsh numbered 96 (Ashley and Davies, 1966a) and were selected on the basis of a general knowledge of Wales and its people and after consultation with colleagues who had such special 
knowledge. The control data comprised a survey of a $2 \%$ sample of the names in the electoral registers of Wales for the years 1963 or 1964 . The proportion of people with Welsh names in the county borough of Swansea was $44 \%$. In the adjacent areas of the county of Glamorgan it was $54 \%$ and in the adjacent area of the county of Carmarthen it was $69 \%$.

TABLE I

DEATHS FROM VASCULAR DISEASE OF CENTRAL NERVOUS SYSTEM IN WALES 1958-1962

\begin{tabular}{c|c|c|c|c|c|c}
\hline & \multicolumn{3}{|c|}{ Males } & \multicolumn{3}{|c}{ Females } \\
\cline { 2 - 5 } \cline { 5 - 7 } & Observed & Expected & Ratio & Observed & Expected & Ratio \\
\hline $\begin{array}{c}\text { High Welsh } \\
\text { Inter- } \\
\text { mediate }\end{array}$ & 2140 & 1674 & 128 & 2975 & 2524 & 118 \\
$\begin{array}{c}\text { Welsh } \\
\text { Low Welsh }\end{array}$ & 6049 & 5103 & 119 & 8088 & 7430 & 109 \\
\hline
\end{tabular}

TABLE II

CASES OF CENTRAL NERVOUS SYSTEM VASCULAR DISEASE IN MALES AT MORRISTON

\begin{tabular}{c|c|c|c}
\hline \multirow{2}{*}{ Home } & \multirow{2}{*}{ Total } & \multicolumn{2}{|c}{ Welsh Names } \\
\cline { 2 - 3 } & & Observed & Expected \\
\hline Swansea & 156 & 78 & 68 \\
Glamorgan & 127 & 71 & $68 \cdot 5$ \\
Carmarthen & 87 & 61 & 60 \\
\hline Total & 370 & 210 & $196 \cdot 5$ \\
\hline
\end{tabular}

Altogether 370 male patients had been admitted to Morriston Hospital, Swansea, with the diagnosis of cerebrovascular disease (Table II). These were subdivided according to whether they lived in Swansea or in the two adjoining county areas, and the number expected to have Welsh surnames was calculated. There was an excess of patients with Welsh surnames in each area but this was not statistically significant.

The death registers of the county borough of Swansea for the years 1957 to 1961 were made available to me by Dr. E. B. Meyrick, the Medical Officer of Health. The names of individuals of both sexes who were domiciled in the county borough and whose death was certified as due to cerebral haemorrhage, cerebral thrombosis, or cerebral embolism were extracted and analysed (Table III). There was a highly significant excess of individuals with Welsh names among the males. The proportion of females with Welsh surnames was lower than that of males but was just significantly in excess of the number expected.
TABLE III

DEATHS FROM VASCULAR DISEASE OF CENTRAL NERVOUS SYSTEM, SWANSEA 1957-1961

\begin{tabular}{l|c|c|c}
\hline & \multirow{2}{*}{ Total } & \multicolumn{2}{|c}{ Welsh Names } \\
\cline { 2 - 4 } & & Observed & Expected \\
\hline Males & 623 & 319 & 272 \\
Females & 808 & 381 & 352 \\
\hline
\end{tabular}

\section{Discussion}

The data presented here show three things. The death rate from vascular disease of the central nervous system is higher in Wales than in England and Wales as a whole. Within Wales deaths from this cause are commonest in the zone in which Welsh is spoken most often and least common in the zone in which spoken Welsh is unusual, this difference is seen after correcting for the different urban/rural distribution of the population in the three zones. Thirdly, there is an excess of Welsh surnames among those suffering from and dying from cerebrovascular disease in and around the town of Swansea.

The most likely explanation of these three observations is that the excess of cerebrovascular disease in Wales is related to differences between the Welsh and the non-Welsh people in the Principality. Observations published elsewhere (Ashley and Davies, 1966a) have shown that there are differences in blood group distribution between the Welsh and non-Welsh people of the Swansea area and that there are few environmental and cultural differences between the two groups. The higher death rate in Wales as a whole and in the more Welsh speaking parts of Wales could be explained on the basis of differences in the environment, in occupations, in habitat, and in culinary preferences, but no such differences exist within the geographically small area of Swansea and its environs. The possible differences due to urban and rural habitat have been corrected in the calculations. The excess of Welshness could be explained on the basis of stratification by age. If there were more people with Welsh surnames in the older age-groups instances of cerebrovascular disease, which tends to affect older people, would be expected to occur in people with Welsh names more often than in those with nonWelsh names. A sample of women delivered of children in this hospital during the year 1962 was analysed. All of these were, of course, much younger than the patients with cerebrovascular disease. The proportion of these women with Welsh surnames was for those living in Swansea $42.5 \%$ and for those living in Glamorgan $57 \%$. These proportions do not differ significantly from 
those found in the survey of electoral registers, and it is concluded that age stratification is not important in the distribution of Welsh names.

The observations in women that there is a higher death rate in the more Welsh speaking areas and that the excess of Welsh names is smaller also support the genetic hypothesis. The majority of adult women bear, as surname, the name of their husband rather than the one which is inherited from their father. The data derived from Welsh speaking (Table I) take no account of the surnames and show an equally large effect in the two sexes; the data on Welsh names (Table III) show a smaller difference in women as many of these counted as having Welsh surnames had non-Welsh maiden names and vice versa. The small excess which was observed may be explained by the suggestion that a woman with a Welsh maiden name is more likely to marry a man with a Welsh surname (Ashley and Davies, 1966a).

I have shown elsewhere (Ashley, 1967) that there is an excess of arteriosclerotic heart disease in Wales and that this too can be related to genetic factors but that differences in serum cholesterol level sufficient to account for this do not exist. Arterioscelerotic diseases of the cerebral vessels and of the coronary vessels are both associated with a similar degenerative process in the walls of the blood vessels. Slack and Evans (1966) have shown an excess of deaths from vascular disease of the central nervous system as well as an excess of deaths from ischaemic heart disease among the first-degree relatives of patients with ischaemic heart disease, and a study of the S.M.Rs. for these two conditions in the hospital regions of England and Wales (Table IV) shows strong and significant positive correlations between cerebrovascular disease in men and women and

TABLE IV

STANDARDIZED MORTALITY RATIO FOR VASCULAR DISEASE OF CENTRAL NERVOUS SYSTEM AND CORONARY ARTERY DISEASE, HOSPITAL REGIONS OF ENGLAND AND WALES, 1964

\begin{tabular}{l|r|r|r|r}
\hline \multirow{2}{*}{ Region } & \multicolumn{2}{|c|}{ Males } & \multicolumn{2}{c}{ Females } \\
\cline { 2 - 5 } \cline { 5 - 5 } & $B_{22}$ & 420 & $B_{22}$ & 420 \\
\hline Newcastle & 115 & 113 & 111 & 125 \\
Leeds & 118 & 115 & 118 & 131 \\
Sheffield & 107 & 92 & 102 & 92 \\
East Anglia & 102 & 97 & 103 & 103 \\
North West Metropolitan & 65 & 86 & 70 & 79 \\
North East Metropolitan & 74 & 93 & 78 & 88 \\
South East Metropolitan & 96 & 99 & 101 & 102 \\
South West Metropolitan & 81 & 93 & 91 & 93 \\
Wessex & 100 & 110 & 102 & 104 \\
Oxford & 81 & 81 & 86 & 81 \\
South Western & 102 & 94 & 105 & 91 \\
Wales & 114 & 112 & 111 & 112 \\
Birmingham & 109 & 93 & 108 & 93 \\
Manchester & 129 & 115 & 122 & 112 \\
Liverpool & 106 & 118 & 99 & 115 \\
& & & & \\
\hline
\end{tabular}

between coronary artery disease in men and women and also between cerebrovascular disease and coronary artery disease in men and between cerebrovascular disease and coronary artery disease in women.

The nature of the genetic defect is uncertain. The association of arteriosclerotic disease of the cerebral and coronary arteries suggests that it may be related to susceptibility to atherosclerosis though the simple chemical possibility of hypercholesterolaemia seems unlikely. The concomitant association of Welshness with gastric carcinoma (Ashley and Davies, 1966b) and prostatic hyperplasia (Ashley, 1966) suggests that a general difference in the ageing process may be responsible, though the finding (Ashley and Davies, 1966c) that there is no excess of lung cancer or of bronchitis in the Welsh militates against this hypothesis.

\section{Summary}

Data on the incidence and distribution of cerebrovascular disease in Wales are presented. There is a higher mortality from this cause in Wales than in England: this is correlated with 'Welshness' determined by Welsh speaking in the country as a whole and determined by the possession of a Welsh surname in the Swansea area.

It is concluded that the difference is genetic in origin and is related to the different gene pools of the Welsh and non-Welsh people of Wales.

This work was carried out under a research grant from the Welsh Hospital Board.

\section{REFERENCES}

Ashley, D. J. B. (1966). Observations on the epidemiology of prostatic hyperplasia in Wales. Brit. F. Urol., 38, 567.

(1967). Coronary artery disease in Wales. F. med. Genet., 4, 277.

- , and Davies, H. D. (1966a). The use of the surname as a genetic marker in Wales. F. med. Genet., 3, 203.

, and - (1966b). Gastric cancer in Wales. Gut, 7, 542

, and - - (1966c). Lung cancer and chronic bronchitis in Wales. Brit. F. prev. soc. Med., 20, 148.

Registrar General (1960). Statistical Review of England and Wales for the Year 1958. PartI. Tables Medical. H.M.S.O., London. (1961). Statistical Review of England and Wales for the Year 1959. Part I. Tables Medical. H.M.S.O., London.

(1962a). Statistical Review of England and Wales for the Year 1960. Part I. Tables Medical. H.M.S.O., London.

- (1962b). Census Report for 1961 on Welsh Speaking Population. H.M.S.O., London.

- (1963). Statistical Review of England and Wales for the Year 1961. Part I. Tables Medical. H.M.S.O., London.

- (1964). Statistical Review of England and Wales for the Year 1962. Part I. Tables Medical. H.M.S.O., London.

(1965). Statistical Review of England and Wales for the Year 1963. Part I. Tables Medical. H.M.S.O., London.

(1966). Statistical Review of England and Wales for the Year 1964. Part I. Tables Medical. H.M.S.O., London.

Slack, J., and Evans, K. A. (1966). The increased risk of death from ischaemic heart disease in first degree relatives of 121 men and 96 women with ischaemic heart disease. f. med. Genet., 3, 239. 